\title{
Study of morphological diversity of traditional aromatic rice landraces (Oryza sativa L.) collected from Assam, India
}

Lipika Lahkar, Bhaben Tanti*

Department of Botany, Gauhati University, Guwahati 781014, Assam, India.

Received: 2017-10-25; Accepted: 2017-11-16

\begin{abstract}
Rice is one of the major cereal grain consumed more than half of the world's population. Aromatic rice is one of the most widely accepted rice due its pleasant aroma. Traditionally, many varieties of aromatic rice are grown by the farmers of Assam maintaining a diverse gene pool. In the present study, morphological variation was studied in 22 aromatic rice landraces using qualitative and quantitative traits. Keteki Joha is very popular indigenous aromatic rice grown in a small pocket of Assam for its high yield. Though Kola Kunkuni Joha is relatively smaller grain size and low yield but have high demand due to its high aroma as compared to other landraces. Significant positive correlations was occurred at 0.05 level between kernel length and seed weight with seed width $\left(\mathrm{r}=0.6734^{*}\right)$ and $\left(0.5881^{*}\right)$ as well as seed weight with kernel width $\left(\mathrm{r}=0.5433^{*}\right)$. The correlation between seed width and kernel width $\left(0.9663^{* *}\right)$ showed significantly positive relationship which shown at 0.01 level. Characterization of aromatic rice landraces of Assam would be a boon for the breeders for designing further rice improvement programme.
\end{abstract}

Keywords: Aromatic rice, diversity, landraces, seed morphology

\section{Introduction}

Nutritionally rice is one of the major cereal grain consumed more than half of the world's population. Scented or aromatic rice is an important commodity worldwide and command premium prices in local and international market over non-scented varieties because of their superior grain quality and pleasant aroma (Nayak et al, 2002). Aromatic rice emits a special aroma with cooking. Aroma is rated the highest desired trait followed by taste and elongation after cooking by Indian consumers (Bhattacharjee et al, 2002). Indian sub-continent is traditionally rich in the diversity of rice including the wild progenitors of cultivated rice (Singh et al., 2001). It is a home for aromatic rice diversity (Bisne and Sarawgi, 2008) and grown in almost all the states, covering more than 30 per cent of the total cultivated area (Adhikari et al., 2012; Chakravorty et al., 2013; Sarma et al., 2016). From the agro horticultural view point North east is the richest reservoir for genetic variability in aromatic rice crops (Hore 2005). Because of the special flavour and economic value, aromatic rice bears special significance in the present globalized era. Traditionally, many varieties of aromatic rice are grown by the farmers of Assam maintaining a diverse gene pool of aromatic rice which differs in various aspects such as aroma intensity, durability, grain shape and size, production potentialities etc. Assam is particularly rich in rice germplasm (Das et al., 2010). The aromatic rice landraces of Assam is a superior class under sali or winter rice especially known as Joha rice. The Joha rice cultivars are favoured for its unique aroma, good cooking qualities and outstanding palatability (Das et al.

\section{*Corresponding Author:}

Dr. Bhaben Tanti, Ph.D.,

Professor, Department of Botany, Gauhati University,

Guwahati 781014, Assam, India.

E-mail: btanti@gauhati.ac.in
2010). Agro-morphological characterization of germplasm accessions is fundamental criteria in order to provide information of plants (Lin, 1991). Diversity studies in rice was done on improved and ancestral rice varieties of Philippines using morphological characters (Caldo et al., 1997; Juliano et al., 1998; Nahar et al., 2016) and on Asian wild cultivated indigenous rice in Yunnan, China (Zeng et al., 2003). Agro-morphological traits, both qualitative and quantitative have been commonly and traditionally used to estimate relationships between genotypes (Goodman, 1972). Though a large number of aromatic rice is existed suiting agro-climatic conditions of Assam but its characterization is not sufficient. The goal of the present study was to characterize morphological characters of native aromatic rice landraces of Assam.

\section{Materials and Methods}

\section{Collection of rice landraces}

22 aromatic landraces were collected from twelve districts viz., Nagaon, Karbi-anglong, Kamrup, Goalpara, Baksa, North lakhimpur, Jorhat, Cachar, Udalguri, Darrang, Dhemaji of Assam during 2015 2016. Areas of these regions were surveyed to get information from farmers about their preference of rice landraces. A diverse collection of short and long kernel, traditional aromatic rice landraces was made (Table 1). The exploration area lies between latitude $24^{\circ} 68 / 52^{/ /} \mathrm{N}$ and longitude $90^{\circ} 62 / \mathrm{E} / /$ to latitude $27^{\circ} 01 / 69 / / \mathrm{N}$ and longitude $95^{\circ} 22^{\circ} 14 / / \mathrm{E}$. It is surrounded on the north by Bhutan and Arunachal Pradesh, on the east by Arunachal 
Pradesh, Nagaland and Manipur, on the west by Meghalaya, Bangladesh and West Bengal, on the south by Tripura and Mizoram.

\section{Methodology adopted and observations recorded}

Random sampling procedure was followed for collection of different landraces. During collection, informal interaction was made with farmers of Assam. Kernel colours were recorded using code number mentioned in colour chart developed by RHS (The Royal Horticultural Society), London, United Kingdom (Royal Horticultural Society, 2015). Some visual observations like Seed coat colours and presence of awn were recorded for 22 rice landraces along with presence or absence of aroma. Rice were measured in grams by weighing 1000 seeds, length and breadth of kernel was also measured with the help of centimeter scale; length and breadth ratio was calculated; presence or absence of awn was observed and different qualitative characters were recorded on the basis of feedback from farmers.

\section{Morphological character analysis}

The morphological descriptors of various morphological characters are presented in Table 1. Observations were recorded on five randomly selected plants for different morphological descriptors viz., 1. Leaf Length (LL) in $\mathrm{cm}$ at heading stage; 2 . Leaf Width $(\mathrm{LW})$ in $\mathrm{cm}$ at heading stage; 3. Leaf Blade Colour (LBC) at stem elongation to heading stage with classes (i) Light green, (ii) Green, (iii) Dark green; 4. Panicle Axis (PnAK) at milk stage to mature stage with classes (i). Straight, (ii) Droopy; 5. Lemma and Palea Colour (LmPC) at mature stage with classes (i) straw, (ii) Black, (iii) Black with golden furrow (iv) Reddish straw (v) Brown with golden patches; seven agronomical traits were recorded, such as 1 . Total tillers per hill (TT/hill), 2. Seed Length in cm, 3. Seed Breadth in $\mathrm{cm}, 4$. Seed Length Breadth ratio (L/B ratio), 5. Kernel Length $(\mathrm{L})$ in $\mathrm{cm}$, 6. Kernel Breadth (B) in $\mathrm{cm}, 7$. Length Breadth ratio $(\mathrm{L} / \mathrm{B}$ ratio) and 8 . Weight of 1000 seeds.

\section{Data analysis and clustering}

Multivariate statistical tools have found extensive use in analyzing, summarizing and describing the inherent variation among crop genotypes. Descriptive statistics of different rice landraces was analyzed by calculating mean, minimum, maximum, standard error and coefficient of variation. Correlation was calculated between seed length, seed breadth, kernel length, kernel breadth, and seed weight. Data were analyzed using XLSTAT version 2017 statistical packages. Cluster analysis of 22 landraces of rice was based on similarity in quantitative parameters (seed length, seed breadth, kernel length, kernel breadth, and kernel weight). A similarity matrix was generated based on the simple Euclidean distance across all accessions of different landraces, and this matrix was used with a hierarchical clustering technique of Ward's Minimum variance method (Ward, 1963; Rao, 1964; Kaufman and Rousseeuw, 1990; Chutia et al., 2012).

\section{Results}

The diversified Joha rice landraces distributed heterogeneously throughout Assam was collected from diverse populations of different places and assembled. Table 1 and Fig. 1 depict the areas of collection (collection sites), variability in some qualitative traits and diversity in aromatic rice landraces as revealed by field surveys and distribution of these landraces in different regions.

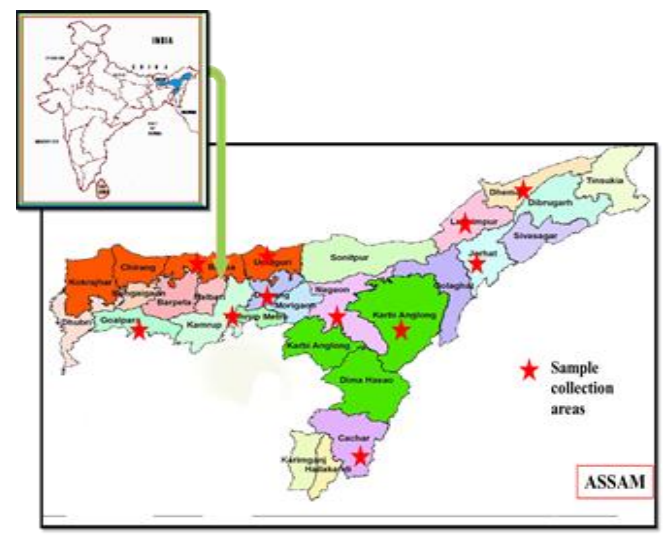

Figure 1. Map showing different sample collection area

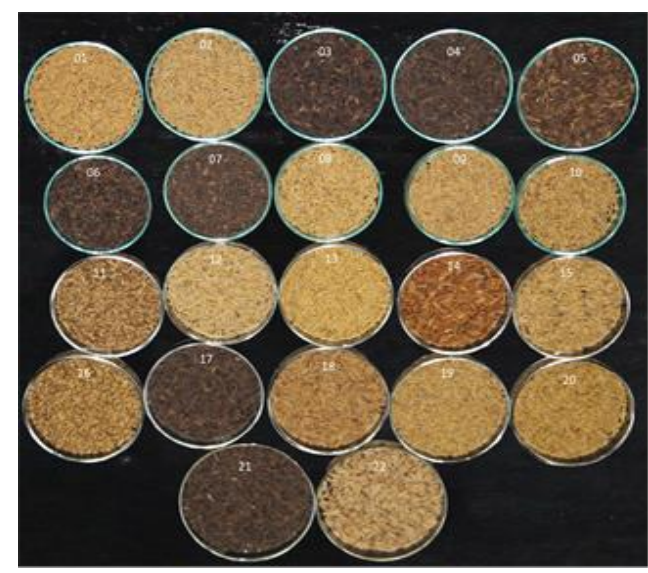

Figure 2. Images of different rice varieties

\section{Variation in qualitative traits}

Discrepency for qualitative traits in Joha rice landraces, mainly for seed coat colour, kernel colour, presence or absence of aroma and awns was recorded (Table 1 and 2; Fig. 2). A total of 14 accessions of landraces had Yellowish White 155B, 2 Greenish White 155C, 4 Pinkish white (N155B), 1 Yellowish Grey 156B and 1White (NN155B) colour. Seed coat colours ranged from Golden (12 landraces), Black (7 landraces), brown (1 landraces), Golden with brown spotted (1 landrace) and Golden with brown in both end ( 1 landrace). The entire 22 collected landraces aroma was present. 21 accessions of the landraces were awn less and only one accessions viz. Kharika Joha was with awn. 
Table 1. Variability studies in 22 traditional aromatic landraces of rice from different districts of Assam, India.

\begin{tabular}{|c|c|c|c|c|c|c|c|}
\hline SL.NO. & $\begin{array}{l}\text { Collector } \\
\text { No. }\end{array}$ & Landrace name & Districts & $\begin{array}{c}\text { Kernal Colour } \\
\text { (Code) }\end{array}$ & Seed Coat Colour & Aroma & $\begin{array}{c}\text { Presence of } \\
\text { Awn }\end{array}$ \\
\hline 01 & LL/BT/001 & Kunkuni Joha & Nagaon & Greenish White 155C & Golden & Present & Awnless \\
\hline 02 & LL/BT/002 & Boga Kunkuni Joha & Goalpara & Greenish White 155C & Golden & Present & Awnless \\
\hline 03 & LL/BT/003 & Kola Kunkuni Joha & Kamrup & Yellowish White155B & Black & Present & Awnless \\
\hline 04 & LL/BT/004 & Kola Joha & Jorhat & Yellowish White 155B & Black & Present & Awnless \\
\hline 05 & LL/BT/005 & Kala Jeera & Cachar & Yellowish White 155B & Black & Present & Awnless \\
\hline 06 & LL/BT/006 & Kola Tulsi Joha & Kamrup & Yellowish White 155B & Black & Present & Awnless \\
\hline 07 & LL/BT/007 & Tulsi Joha & Baksa & Yellowish White 155B & Black & Present & Awnless \\
\hline 08 & LL/BT/008 & $\begin{array}{l}\text { Jwsa Gufur } \\
\text { (Phisa-jhar) }\end{array}$ & Udalguri & Yellowish White 155B & Golden & Present & Awnless \\
\hline 09 & LL/BT/009 & Boga Joha & Darrang & Yellowish White 155B & Golden & Present & Awnless \\
\hline 10 & LL/BT/010 & Badsahbhog Joha & Baksa & Yellowish White 155B & Golden & Present & Awnless \\
\hline 11 & LL/BT/011 & Betguti Joha & Baksa & Pinkish White N155B & $\begin{array}{l}\text { Golden with brown } \\
\text { spotted }\end{array}$ & Present & Awnless \\
\hline 12 & LL/BT/012 & Kharika Joha & Kamrup & Yellowish Grey 156B & Golden & Present & Awned \\
\hline 13 & LL/BT/013 & Mukuta Joha & North Lakhimpur & Yellowish White 155B & Golden & Present & Awnless \\
\hline 14 & $\mathrm{LL} / \mathrm{BT} / 014$ & Rampal Joha & Kamrup & Pinkish White N155B & Brown & Present & Awnless \\
\hline 15 & LL/BT/015 & Keteki Joha & North Lakhimpur & Pinkish White N155B & Golden & Present & Awnless \\
\hline 16 & LL/BT/016 & Gobinda Tulsi Joha & North Lakhimpur & Pinkish White N155B & $\begin{array}{l}\text { Golden with brown } \\
\text { in both end }\end{array}$ & Present & Awnless \\
\hline 17 & LL/BT/017 & Dangor Joha & Dhemaji & Yellowish White 155B & Black & Present & Awnless \\
\hline 18 & LL/BT/018 & Kon Joha & Jorhat & Yellowish White 155B & Golden & Present & Awnless \\
\hline 19 & LL/BT/019 & Guti Joha & Jorhat & Yellowish White 155B & Golden & Present & Awnless \\
\hline 20 & LL/BT/020 & Nepali joha & Baksa & Yellowish White 155B & Golden & Present & Awnless \\
\hline 21 & LL/BT/021 & Krishna joha & Jorhat & Yellowish White 155B & Black & Present & Awnless \\
\hline 22 & LL/BT/022 & Joha Bora & Karbi Anglong & White NN155B & Golden & Present & Awnless \\
\hline
\end{tabular}

Characteristics revealed by different farmers about local landraces were recorded and presented in Table 2. Among the landrace diversity, Kola Kunkuni Joha and Kola Tulsi Joha, were highly aromatic types collected from this region. The production of Keteki Joha was maximum and Kunkuni Joha have minimum among the aromatic rice landraces of this region. The landrace Joha Bora is moderately aromatic, more sticky than other landrace and traditionally useful for the preparation of rice beer.

\section{Morphological characters}

Five morphological characters were recorded for 22 collected aromatic rice landraces. The morphological characters included leaf length (1), leaf width (2), leaf blade colour (3), Panicle Axis (4), lemma and palea colour (5), and the results of morphological characters recorded for 22 accessions are discussed in Table. 3 (Character 1 to 5). The leaf length ranges from $71.5 \mathrm{~cm}$ (Joha Bora) to $32.2 \mathrm{~cm}$ (Badsahbhog Joha). Leaf breadth of collected aromatic rice landraces ranges in between $0.8-1.4 \mathrm{~cm}$. Out of 22 collected aromatic rice landraces 9 light green, 5 dark green and 8 were green in leaf blade colour, Except 6 landraces all the others have straight panicle axis. Maximum number of landraces has straw and black color of Lemma and palea.

Table 2. Characteristic features recorded in 22 landraces of rice based on feedback from farmers

\begin{tabular}{llll}
\hline SL. NO. & Landrace name & Specific note recorded from farmers & Remarks \\
\hline 01 & Kunkuni Joha & Aromatic, low production & Feedback from farmers \\
02 & Boga Kunkuni Joha & Aromatic & Feedback from farmers \\
03 & Kola Kunkuni Joha & Highly Aromatic & Feedback from farmers \\
04 & Kola Joha & Aromatic, & Feedback from farmers \\
05 & Kala Jeera & Aromatic, & Feedback from farmers \\
06 & Kola Tulsi Joha & Highly Aromatic, & Feedback from farmers \\
07 & Tulsi Joha & Aromatic, & Feedback from farmers \\
08 & Jwsa Gufur (Phisa-jhar) & Aromatic, & Feedback from farmers \\
09 & Boga Joha & Aromatic, & Feedback from farmers \\
10 & Badsahbhog Joha & Aromatic, & Feedback from farmers \\
11 & Betguti Joha & Aromatic, & Feedback from farmers \\
12 & Kharika Joha & Aromatic, & Feedback from farmers \\
13 & Mukuta Joha & Aromatic, & Feedback from farmers \\
14 & Rampal Joha & Aromatic, & Feedback from farmers \\
15 & Keteki Joha & Aromatic, Good yield & Feedback from farmers \\
16 & Gobinda Tulsi Joha & Aromatic, & Feedback from farmers \\
17 & Dangor Joha & Aromatic, & Feedback from farmers \\
18 & Kon Joha & Aromatic, & Feedback from farmers \\
19 & Guti Joha & Aromatic, & Feedback from farmers \\
20 & Nepali joha & Aromatic, & Feedback from farmers \\
21 & Krishna joha & Aromatic, & Feedback from farmers \\
22 & Joha Bora & Moderately Aromatic, Sticky, traditionally & Feedback from farmers \\
\hline
\end{tabular}


Table 3. Various morphological characteristic features recorded in 22 landraces of rice

\begin{tabular}{|c|c|c|c|c|c|c|c|}
\hline SL.NO. & Landrace name & $\begin{array}{c}\text { No } \\
\text { of } \\
\text { tiller }\end{array}$ & $\begin{array}{l}\text { Length of leaf } \\
(\mathrm{cm}) \text { at } \\
\text { heading stage }\end{array}$ & $\begin{array}{l}\text { Breadth of leaf } \\
(\mathrm{cm}) \text { at heading } \\
\text { stage }\end{array}$ & $\begin{array}{l}\text { Leaf blade colour at } \\
\text { stem elongation to } \\
\text { heading stage }\end{array}$ & $\begin{array}{c}\text { Panicle Axis } \\
(\text { PnAK) at milk } \\
\text { stage to mature }\end{array}$ & $\begin{array}{l}\text { Lemma and Palea } \\
\text { Colour (LmPC }\end{array}$ \\
\hline 01 & Kunkuni Joha & 3 & \multirow{2}{*}{$\begin{array}{l}58.8 \\
61.2\end{array}$} & 1.1 & Light green & Straight & Straw \\
\hline 02 & Boga Kunkuni Joha & 3 & & 1.4 & Light green & Straight & Straw \\
\hline 03 & Kola Kunkuni Joha & 3 & 43.5 & 0.9 & Light green & Straight & Black with golden furrow \\
\hline 04 & Kola Joha & 2 & 54.5 & 1.0 & Light green & Straight & Black \\
\hline 05 & Kala Jeera & 2 & 57.2 & 0.8 & Light green & Straight & Black with golden patches \\
\hline 06 & Kola Tulsi Joha & 2 & 68.4 & 1.1 & Drak green & Straight & Black with golden patches \\
\hline 07 & Tulsi Joha & 2 & 46.6 & 0.9 & Green & Straight & Black with golden patches \\
\hline 08 & $\begin{array}{c}\text { Jwsa Gufur (Phisa- } \\
\text { jhar) }\end{array}$ & 3 & 60.2 & 1.3 & Light green & Straight & Straw \\
\hline 09 & Boga Joha & 4 & 66.3 & 1.1 & Green & Straight & Straw \\
\hline 10 & Badsahbhog Joha & 3 & 32.8 & 1.2 & Green & Straight & Straw and brown \\
\hline 11 & Betguti Joha & 4 & 54.2 & 1.2 & Green & Straight & Straw with brown patches \\
\hline 12 & Kharika Joha & 5 & 48.9 & 1.1 & Drak green & Dropy & Straw \\
\hline 13 & Mukuta Joha & 4 & 43.5 & 0.8 & Light green & Straight & Straw \\
\hline 14 & Rampal Joha & 6 & 43.5 & 0.9 & Green & Dropy & Brown with golden patches \\
\hline 15 & Keteki Joha & 6 & 40.1 & 1.2 & Drak green & Dropy & Straw \\
\hline 16 & Gobinda Tulsi Joha & 4 & 38.9 & 1.1 & Green & Straight & Straw with brown patches \\
\hline 17 & Dangor Joha & 4 & 61.9 & 0.8 & Drak green & Dropy & Black \\
\hline 18 & Kon Joha & 3 & 38.9 & 0.9 & Light green & Straight & Reddish straw \\
\hline 19 & Guti Joha & 3 & 50.5 & 1.3 & Light green & Straight & Straw \\
\hline 20 & Nepali joha & 4 & 59.8 & 1.0 & Green & Straight & Straw \\
\hline 21 & Krishna joha & 3 & 56.3 & 1.2 & Green & Dropy & Black \\
\hline 22 & Joha Bora & 5 & 71.5 & 1.4 & Drak green & Dropy & Light straw \\
\hline
\end{tabular}

\section{Agronomical characters}

22 landraces of traditional aromatic rice group were evaluated for agronomical traits like total tillers per hill were recorded from five competitive plants of middle row of each entry. The tiller number per hill ranges in between 2 to 6 . Keteki Joha have maximum i.e. 6 tiller/hill.

\section{Variation in quantitative traits}

The landraces was unusual in the seed morphological characters. Variability was also measured for quantitative traits (Table 4) of rice landraces particularly for kernel length with and without husk, kernel breadth with and without husk, ratio $1 / \mathrm{b}$ (with husk), ratio $1 / \mathrm{b}$ (without husk) and 1000 kernel weight (g). Maximum seed length $8.80 \mathrm{~mm}$ was recorded for Keteki Joha while minimum seed length was $5.00 \mathrm{~mm}$ in Joha Bora. Maximum seed breadth $(5.00 \mathrm{~mm})$ was recorded for
Krishna Joha and Joha Bora while minimum seed breadth $(1.50 \mathrm{~mm})$ was recorded for Kunkuni Joha. Maximum kernel length $7.00 \mathrm{~mm}$ was recorded for Keteki Joha and Rampal Joha while minimum kernel length was $4.00 \mathrm{~mm}$. Maximum kernel breadth $(4.00 \mathrm{~mm})$ was recorded for Krishna Joha and Joha Bora while minimum kernel breadth $(1.10 \mathrm{~mm})$ was recorded for Kunkuni Joha. Maximum kernel weight $(17.29 \mathrm{~g})$ was recorded (Table 4) for Kharika Joha while minimum kernel weight $(9.77 \mathrm{~g})$ was recorded for Betguti Joha. Rice landraces germplasm showed considerable variability for quantitative traits as indicated by coefficients of variation (CV) (Table 4). Among the traits studied the highest variability (CV per cent) was observed for 1000 kernel weight (29.31) followed by ratio of kernel length/breadth without husk (20.21), ratio of kernel length/breadth with husk (17.06) and kernel breadth without husk (16.60).

Table 4. Descriptive statistics of different rice landraces collected from different districts of Assam, India.

\begin{tabular}{lllllll}
\hline S1. No. & \multicolumn{1}{c}{ Variables } & \multicolumn{1}{c}{ Minimum } & \multicolumn{1}{c}{ Maximum } & \multicolumn{1}{c}{ Mean } & \multicolumn{1}{c}{ SE Mean } \\
\hline 1 & Kernel length with husk $(\mathrm{mm})$ & 5.00 & 8.80 & 6.20 & 0.034 & 18.24 \\
2 & Kernel length with husk $(\mathrm{mm})$ & 4.00 & 7.00 & 5.30 & 0.006 & 88.33 \\
3 & Kernel breadth with husk (mm) & 1.50 & 5.00 & 2.60 & 0.02 & 13 \\
4 & Kernel breadth without husk (mm) & 1.10 & 4.00 & 2.10 & 0.003 & 70 \\
5 & Ratio l/b (with husk) & 1.76 & 3.33 & 2.39 & 0.17 & 14.06 \\
6 & Ratio l/b (without husk) & 1.5 & 3.68 & 2.68 & 0.2 & 13.4 \\
7 & 1000 Kernel weight (g) & $9.77 \mathrm{~g}$ & $17.29 \mathrm{~g}$ & 12.56 & 0.33 \\
\hline
\end{tabular}


Table. 5 Pearson correlation coefficients among quantitative characters in aromatic landraces

\begin{tabular}{llllll}
\hline & Seed Length & Seed breadth & Kernel Length & Kernel breadth & Seed weight \\
\hline Seed Length & 1 & & & & \\
Seed breadth & -0.0394 & 1 & & & \\
Kernel Length & -0.0397 & $0.6734^{*}$ & 1 & & \\
Kernel breadth & -0.0264 & $0.9663^{* *}$ & $0.6551^{*}$ & 1 & \\
Seed weight & 0.4096 & $0.5881^{*}$ & 0.3113 & $0.5433^{*}$ & 1 \\
\hline
\end{tabular}

Correlations among quantitative characters

The correlation matrix showed the relationships among the analyzed quantitative characters values of seed length, seed width, kernel length, kernel width and seed weight the twenty-two traditional aromatic rice landraces (Table 5). Significant positive correlations between Kernel Length and Seed weight with Seed breadth $\left(\mathrm{r}=0.6734^{*}\right)$ and $\left(0.5881^{*}\right)$ respectively as well as Seed weight with Kernel breadth $\left(\mathrm{r}=0.5433^{*}\right)$ were shown at the 0.05 level, which indicates that rice landraces high in weight may likely to be high Kernel Length, Seed breadth and Kernel breadth. The correlation between Seed breadth and Kernel breadth $\left(0.9663^{* *}\right)$ showed significantly positive relationship which shown at 0.01 level (Table. 5).

\section{Cluster analysis}

Cluster analysis based on quantitative characters and distance matrices is given in Fig. 3. Dendrogram have indicated two major cluster groups. Major cluster - I comprised 10 landraces while cluster - II comprises 12 landraces. Cluster - I further grouped in two sub-clusters based on similarity in quantitative characters seed type and kernel type was of Boga Joha, Badsahbhog Joha, Gobinda Tulsi Joha, Keteki Joha and Boga Kunkuni Joha (5 landraces) in sub-group (A). In sub-group (B) landraces like Guti Joha, Betguti Joha, Mukuta Joha, Jwsa Gufur Phisa Jhar and Kala Jeera (5 landraces) were grouped on the basis on similarity in quantitative characters.

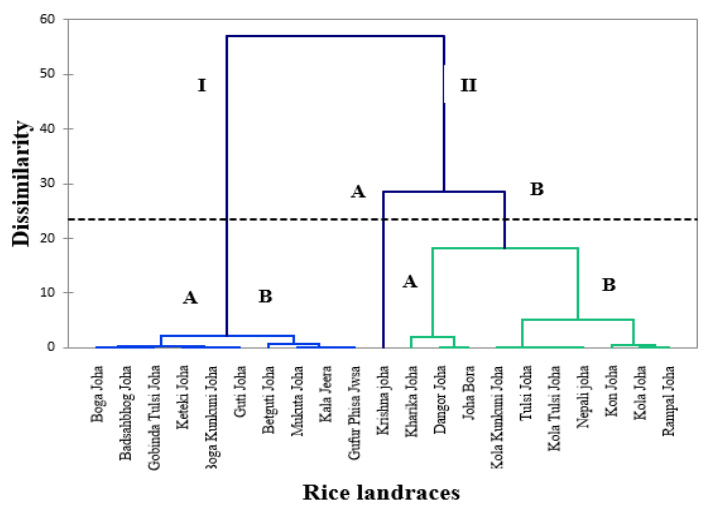

Figure 3. Dendrogram generated by Ward's method based on similarity in quantitative parameters (seed size, kernel size, and kernel weight) for 22 rice landraces collected from Assam, India.

Cluster II also grouped further in two sub-clusters based on similarity in characters like maximum 1000 kernel weight with Krishna Joha (A) which form a group. The (B) sub-group further divided into two subgroups consisting landraces like Kharika Joha, Dangor Joha and Joha Bora (3 landraces) sub group (a) and Kola Kunkuni Joha, Tulsi Joha, Kola Joha, Kola Tulsi Joha, Nepali Joha, Kon Joha and Rampal Joha sub group (b) depending on the similar quantitative characters and traits like kernel types. The accessions in clusters (I) and (II) are distant, and some traits like seed size, kernel size, seed coat colour, aroma, 1000 kernel weight and presence of awn help to form same cluster which can be help in the crosses successfully for distinct traits that might helpful in plant breeding programme. Different landraces collected from diverse areas of Assam were clustered together.

\section{Discussion}

The magnitude of genetic variability and the extent to which the desirable characters are heritable (Ravi et al., 2003) is the basis of successful crop improvement programme. For assessing genetic diversity among morphologically distinguishable rice cultivars in aromatic rice cultivars from Asia morphological traits were useful for preliminary evaluation (Hien et al., 2007). Analysis of genetic variability in landraces of traditional rice landraces can help in identifying diverse parental combinations for further selection and to help introgression desirable genes (Semwal et al., 2014).

\section{Morphological data}

The results presented here, for landraces from Assam, reveal high diversity of $\mathbf{B}$ landraces. Maximum kernel length $(0.7 \mathrm{~cm})$ was recorded for Keteki Joha and Rampal Joha while minimum kernel length was $0.4 \mathrm{~cm}$ in Kunkuni Joha. Maximum kernel breadth $(0.4 \mathrm{~cm})$ was recorded for Krishna Joha and Joha Bora while minimum kernel breadth $(0.11 \mathrm{~cm})$ was recorded for Kunkuni Joha. During household survey it was observed that these landraces were cultivated by many farmers for over a long period of time. Similar results were also reported in rice by several workers (Patra, 2000; Deb, 2000; Singh et al., 2005; Chakravorty and Ghosh, 2011; Mishra and Sinha, 2012; Tirkey et al., 2013; Semwal, et al., 2014). Due to unique morphological characters of seeds and adaptability to local environments, the landraces are known for significant variability (Frainkel et al., 1995; Hore, 2005). Rice landraces collected from Assam were studied and significant variability was noted for vegetative and seed characters involving different quantitative traits. 
Areas of collection of landraces and data analysis

In the present investigation, 22 aromatic rice landraces of Assam were mainly analysed for variability in seed morphology which showed the diversity for morphological characters. Landrace like Keteki Joha is very popular indigenous aromatic rice grown in a small pocket of Assam for its high yield. Landrace Kola Kunkuni Joha though is relatively smaller sized seed of black colour and low yield but had high marketability due to its high aroma as compared to other landraces. Several studies were carried out using morphological and molecular markers in different cereal species (Glaszmann, 1987; Thanh et al., 1999; Sun et al., 2001; Zhang et al., 1994). Analysis of diversity with traditional landraces like Kalo, Rato, Seto, Marshi, Mehele and Darime based on traits like colour of grain, length of kernel, period of maturity etc., showed low level of morphological and molecular diversity (Chakravorty and Ghosh, 2013). For the latter, adaptation, selection and cultural variation were probably responsible for variability among the different landraces from same region.

\section{Conclusions}

In conclusion, the present investigation provides the guidelines for the selection of parents based on agronomic traits with special reference to qualitative characters for rice improvement program. Many of these landraces are poor yielder and grown only in restricted pockets in the area of collection. Special drive is desirable for their collection and conservation. Due to the significant aroma, good taste and their regional importance local farmers are conserving these landraces from generation to generation. The traits recorded during germplasm collection are listed on the basis of feedback from farmers and present data gives preliminary observations and require further validation after characterization/evaluation. In rice improvement program characterization of landraces could help breeders to utilize appropriate characters. The present investigation provides the base material for the rice breeders for exploitation of landraces possessing one or more desirable characters.

\section{Acknowledgements}

Funding support received from Department of Biotechnology (DBT), Govt. of India for the research project entitled "Development of high yielding, non-lodging and biotic resistant varieties of black scented rice of Manipur and joha rice of Assam through biotechnological intervention" vide sanction number DBT-NER/AGRI/29.2015, dt. $19 / 10 / 2016$ is greatly acknowledged.

\section{References}

1. Adhikari B, MK Bag, MK Bhowmick, C Kundu, Rice in West Bengal-rice knowledge management portal (www.rkmp.co.in), Directorate of Rice
Research, Rajendranagar, Hyderabad, Andhra Pradesh, 2012: 88.

2. Bhattacharjee P, SR Singhal, RP Kulkarni, Basmati rice: A review. International Journal of Food Sci Technol, 37.1 (2002): 1-12.

3. Bisne R, AK Sarawgi, Agro-morphological and quality characterization of Badshah bhog group from aromatic rice germplasm of Chhattisgarh Bangladesh, J. Agril. Res., 33.3 (2008): 479-492.

4. Caldo RA, LS Sebastian, JE Hernandez, Diversity of Philippines improved rice varieties and their progenitors using morphological and molecular markers. Philip J Crop Sci, 22 (1997): 11-26.

5. Chakravorty A, PD Ghosh, An analysis on genetic parameters of different landraces of rice of West Bengal. J Crop Weed, 7 (2011): 59-63.

6. Chakravorty A, PD Ghosh, Characterization of Landraces of Rice from Eastern India. Ind J Plant Genet Resour., 26.1 (2013): 62-67.

7. Chakravorty A, PD Ghosh, PK Sahu, Multivariate analysis of phenotypic diversity of landraces of rice of West Bengal. Am J Exp Agri, 3 (2013): 110-123.

8. Chutia J, SP Borah, B Tanti, Effect of drought stress on protein and proline metabolism in seven traditional rice (Oryza sativa Linn.) genotypes of Assam, India, Journal of Research in Biology, 2.3 (2012) 206-214.

9. Das A, V Tushar, Kesari and L Rangan, Aromatic joha rice of assam- a review, Agric. Rev., 31.1 (2010): $1-10$.

10. Deb D, Folk rice varieties of West Bengal: agronomic and morphological characteristics. Research Foundation for Science Technology \& Ecology, New Delhi, 2000.

11. Frankel $\mathrm{OH}$, AHD Brown, JJ Burdon, The conservation of plant biodiversity. Cambridge University Press, London 1995.

12. Glaszmann JC, Isozymes and classification of Asian rice varieties. Theor Appl Genet, 74(1987): 21-30.

13. Goodman MM, Distance analysis in biology. Syst Zool, 21 (1972): 174-186.

14. Hien NL, WA Sarhadi, Y Hirata, Y Oikawa, Genetic diversity of morphological responses and relationships among Asia aromatic rice (Oryza sativa L.) cultivars. Tropics, 16.4 (2007):343-355.

15. Hore DK, Rice diversity collection, conservation and management in north-eastern India. Genet Resour Crop Evol, 52 (2005): 1129-1140.

16. Juliano AB, EB Naredo, MT Jackson, Taxonomic status of Oryza glumaepatula Steud. I. Comparative morphological studies of new world diploids and Asian AA genome species. Genet Resour Crop Evol, 45 (1998): 197-203. 
17. Kaufman L, PJ Rousseeuw, finding groups in data: an introduction to cluster analysis. Wiley, New York, 1990 .

18. Lin MS, Genetic base of japonica rice varieties released in Taiwan., Euphytica, 56 1991.: 43-46.

19. Mishra PK, AK Sinha, Rice diversity in Bankura district of West Bengal (India). Bios Discov, 3 (2012): 284-287.

20. Nahar S, J Kalita, L Sahoo, B Tanti, Morphophysiological and molecular effects of drought stress in rice, Annals of Plant Sciences, 5.9 (2016) 1409-1416.

21. Nayak AR, D Chaudhury, JN Reddy, Genetic variability, heritability and genetic advance in scented rice. Indian J Agrl Sci, 46.12 (2002): 45-47.

22. Patra BC, Collection and characterization of rice genetic resources from Keonjhar district of Orissa. Oryza, 34 (2000): 324-326.

23. Rao CR, Advance statistical methods in biometrical research. John Wiley and Sons. Inc., New York, 1964 351-364.

24. Ravi M, S Geethanjali, F Sameeyafarheen, M Maheswaran, Molecular marker based genetic diversity analysis in rice (Oryza sativa L.) using RAPD and SSR markers. Euphytica, 133 (2003): 243252.

25. Royal Horticultural Society RHS colour chart (edn.3), The Royal Horticultural Society, London, United Kingdom, 2015.

26. Sarma B, NR Basumatary, S Nahar, B Tanti, Effect of drought stress on morpho-physiological traits in some traditional rice cultivars of Kokrajhar district, Assam, India, Annals of Plant Sciences, 5.8 (2016): 1402-1408.

27. Semwal DP, A Pandey, DC Bhandari, OP Dhariwal, SK Sharma Variability study in seed morphology and uses of indigenous rice landraces (Oryza sativa L.) collected from West Bengal, India, Ajcs, 8.3 (2014):460-467.
28. Singh BN, SR Dhua, RK Sahu, BC Patra, BC Marndi, Status of rice germplasm-Its collection and conservation in India Indian J. Plant. Genet Resour., 14 (2001): 105-106.

29. Singh SP, SS Malik, AK Singh, Collection of rice landraces from Vindhayachal hills. Agric Sci Digest 25 (2005): 174-177.

30. Sun CQ, XK Wang, ZC Li, A Yoshimura, N Iwata, Comparison of the genetic diversity of common wild rice (Oryza rufipogon Griff.) and cultivated rice (O. sativa L.) using RFLP markers. Theor Appl Genet., 102 (2001): 157-162.

31. Thanh ND, HG Zheng, NV Dong, LN Trinh, ML Ali, HT Nguyen, Genetic variation in root morphology and microsatellite DNA loci in upland rice (Oryza sativa L.) from Vietnam. Euphytica, 105 (1999): 43-51.

32. Tirkey A, AK Sarawgi, LV Subbarao, Studies on Genetic Diversity in Various Qualitative and Quantitative Characters in Rice Germplasm. Ind J Plant Genet Resour, 26.2 (2013): 132-137.

33. Ward Jh Jr, Hierarchical grouping to optimize an objective function. I Am Stat Assoc, 48 (1963): 236244.

34. Zeng Y, S Shen, Z Li, Z Yang, X Wang, H Zhang, $\mathrm{G}$ Wen, Eco-geographic and genetic diversity based on morphological characters of indigenous rice (Oryza sativa L.) in Yun- nan, China. Genet Resour Crop Evol, 50 (2003): 567-577.

35. Zhang QF, GP Yang, XK Dai, JZ Sun, A comparative analysis of genetic polymorphism in wild and cultivated barley from Tibet using isozyme and ribosomal DNA markers. Genome, 37 (1994): 631-638.

\section{Cite this article as:}

Lipika Lahkar and Bhaben Tanti. Study of morphological diversity of traditional aromatic rice landraces (Oryza sativa L.) collected from Assam, India. Annals of Plant Sciences 6.12 (2017) pp. 1855-1861.

doi: http://dx.doi.org/10.21746/aps.2017.6.12.9 